\title{
Use of a serum-free medium to produce in vitro Neospora caninum and Toxoplasma gondii tachyzoites on Vero cells
}

\author{
François De MeErschmana*, Chantal Rettigner ${ }^{a}$, Charles Focanta, \\ Raphael BoreuX ${ }^{a}$, Christian PINSET ${ }^{b}$, Thierry LECLIPTEUX ${ }^{\mathrm{a}}$, \\ Bertrand LossONa
}

\begin{abstract}
${ }^{a}$ Laboratory of Parasitology and Pathology of Parasitic diseases, Faculty of Veterinary Medicine, University of Liege, Bd de Colonster, 20, Building 43a, B-4000 Sart-Tilman, Liège, Belgium

${ }^{\mathrm{b}}$ Laboratoire de développement cellulaire, Institut Pasteur, rue du docteur Roux,
\end{abstract} 75724 Paris Cedex 15, France

(Received 4 May 2001; accepted 18 September 2001)

\begin{abstract}
Neospora caninum and Toxoplasma gondii are cyst-forming coccidian parasites of human and veterinary clinical relevance. In vitro cultivation of the protozoans using Vero cells is usually performed in order to produce antigenic materials. Quantitative and qualitative comparisons of Vero cells grown in RPMI medium supplemented either with foetal calf serum (FCS), horse serum (HS) or a specific serum-free additive (DefCell) were performed. A serum-free cell culture system used to propagate $N$. caninum (NC-1 isolate) and T. gondii tachyzoites ( $\mathrm{Rh}$ stain) were compared with the other two cell culture systems. FCS supplemented media was found to be more effective than the others in promoting Vero cells and N. caninum tachyzoites. However, it was found unable to support adequate $T$. gondii tachyzoite proliferation. Vero cells, $T$. gondii and $N$. caninum tachyzoite production gave similar growth patterns with either HS or DefCell supplemented media. Defcell was considered as a good alternative to supplement culture medium.
\end{abstract}

Neospora caninum / Toxoplasma gondii / cell culture / serum-free medium

Résumé - Utilisation d'un milieu sans sérum pour la production in vitro de tachyzoites de Neospora caninum et Toxoplasma gondii sur cellules Vero. Neospora caninum et Toxoplasma gondii sont deux sporozoaires présentant un intérêt en médecine humaine et vétérinaire. La culture in vitro utilisant, entre autres, les cellules Vero comme support de la multiplication des deux parasites, est généralement employée en vue de l'obtention de tachyzoïtes. Au cours de cette étude, une évaluation quantitative et

*Correspondence and reprints

Tel.: (32) 43664098; fax: (32) 43664097; e-mail: Francois.DeMeerschman@ulg.ac.be 
qualitative de la production de cellules Vero dans un milieu complémenté en sérum de veau fœtal, de cheval ou bien avec un additif (DefCell) exempt de sérum, a été réalisée. Les trois types de milieu de culture ont également été employés et comparés dans le cadre de la production sur cellules Vero de tachyzoïtes de $T$. gondii (souche RH) et de $N$. caninum (isolat NC-1). Le milieu complémenté en sérum de veau fotal s'est révélé être le plus adéquat pour la croissance de cellules Vero et la production de tachyzoïtes de $N$. caninum. Cependant, ce milieu s'est avéré incapable d'assurer une production optimale de tachyzoïtes de $T$. gondii. La production de cellules Vero, ainsi que de tachyzoïtes de $T$. gondii et de $N$. caninum, a présenté des caractéristiques communes en milieu complémenté en sérum de cheval et en DefCell. Ce dernier s'est révélé être une bonne alternative au sérum de veau foetal et de cheval pour complémenter les milieux de culture. L'absence de protéines animales dans ce milieu présente un certain nombre d'avantages qui sont discutés.

\section{Neospora caninum / Toxoplasma gondii / cellules Vero / milieu exempt de sérum}

\section{INTRODUCTION}

Neospora caninum and Toxoplasma gondii are two tissue-cyst-forming protozoa of the Sarcocystidae family in the Apicomplexa phylum. Neosporosis is now recognized as a major cause of bovine abortion and stillbirth in cattle throughout the world [12]. Neuromuscular clinical signs and sometimes ulcerative dermatitis may occur in $N$. caninum infected dogs $[13,14$, 16, 36, 37]. Additionally, serological evidence of $N$. caninum infection in humans has been recorded in the United States during screening of blood donors by Indirect Fluorescent Antibody Test (IFAT) and immunoblotting. The significance of human exposure to this parasite is still unde termined [41]. The related parasite $T$. gondii is responsible for abortions and congenital infections in sheep, goats (for review see [7]) and humans [40] and disseminated toxoplasmosis is a severe disease in immunocompromised patients. However, T. gondii is not regarded as abortifacient in cattle although $T$. gondii specific DNA was recently detected by polymerase chain reaction (PCR) in damaged foetal brains, showing histo-pathological lesions consistent with a protozoan infection $[18,20]$.

Accurate diagnosis leads to a better understanding of the epidemiology of $N$. caninum, a potential cause of abortion in cattle. The diagnosis of neosporosis is based on post mortem of foetuses, antigen and/or parasite-host interactions evaluated by either histopathology or immunochemistry [27, 46]. These techniques are quite specific but are either time consuming or lacking sensitivity. IFAT [5] or antigen-capture and inhibition ELISAs [4, 6, 23] are widely used. PCR and DNA hybridization assays are mainly used in research laboratories to demonstrate the presence of $N$. caninum DNA in tissues [18, 42]. However, the suitability of these methods for practical use on autolysed or mummified foetuses needs to be further evaluated [45].

The production of antigenic material and the study of the relationship between the host cell and the parasites require in vitro cultivation of the protozoan. Tachyzoites of $N$. caninum and $T$. gondii have been cultivated in primary cells as well as in established lines $[13,28,30]$. The culture medium is usually supplemented with foetal calf serum (FCS). Some batches of foetal calf serum can cause agglutination and poor growth of the tachyzoites [22] and the presence of FCS can be responsible for a high background signal when using IFAT or ELISA. Horse serum (HS) has been proposed as an alternative to FCS. However, two sero-epidemiological surveys performed in North America using the $N$. caninum Agglutination Test (NAT) or IFAT have demonstrated that 11.5 and $23.3 \%$ of horse sera regarded as positive respectively 
$[8,17]$. Recently, $N$. hughesi was identified in the horse in California [31]. Since $N$. caninum cross reacts serologically with this new species [31], seroconversion is indicative of exposure to either of these two parasites. The use of horse serum could, therefore, also lead to unexpectedly high background values when performing IFAT or ELISA.

In the present study, serum-free medium was evaluated in order to eliminate high background values when using serological techniques such as IFAT $[2,9,15,33]$, and ELISA [26, 32, 34, 44].

\section{MATERIALS AND METHODS}

\subsection{Cell Culture}

Comparisons were performed with three different media on Vero cells. Some cells were adapted to RPMI (BioMedia, Boussens, France) serum-free medium containing 10\% specific additives (DefCell) (Institut Pasteur, Paris, France) while another batch had previously been adapted to grow in 2\% RPMI enriched with heat-inactivated horse serum (Sera-Lab, Loughborough, United Kingdom). Vero cells grown routinely in RPMI containing $10 \%$ heat-inactivated FCS (Sera$\mathrm{Lab}$ ) were maintained as a standard. Both FCS and HS were found to be free of antibodies to $T$. gondii using a commercially available test (Toxo-Screen, Bio-Mérieux, Brussels, Belgium). Furthermore, no IgG antibodies to $N$. caninum were detected by IFAT [11] in FCS and HS after modifying the test for use in the horse. The cells were observed at $100 \times$ magnification in order to evaluate when they became confluent. The RPMI medium was supplemented with stabilised glutamine (Glutamax), nonessential amino acids, sodium pyruvate, with $100 \mathrm{U} / \mathrm{mL}$ of penicillin and $100 \mu \mathrm{g} / \mathrm{mL}$ of streptomycin (Biomedia). Tachyzoites of $N$. caninum (NC-1 isolate) [13] as well as $T$. gondii tachyzoites (RH strain) had been previously grown in Vero cells in a foetal calf sera supplemented medium. After cell adaptation in a serum-free medium, the growth of both species of tachyzoites was evaluated in the adapted cell lines.

\subsection{Cell count}

Cell cultures were maintained in batches of 24 T 25 flasks (Corning, New York, USA) at a time. Cell growth was evaluated both qualitatively and quantitatively. Examinations were made daily at $100 \times$ magnification using an inverted microscope equipped with phase contrast. Cell morphology and the ratio between living and dead cells were recorded. Counts were performed using Trypan blue dye (0.4\%) (Flow Laboratories, Edinburgh, UK) in order to evaluate the number of dead cells. For each parasite medium combination, a quantitative evaluation was performed on eight flasks, one flask of each combination being used each day for trypsinisation and cell counts. For each flask, cell counts were repeated seven times with a Thoma haemocytometer. Briefly, culture medium was discarded and cells were washed with $5 \mathrm{~mL}$ sterile PBS before trypsinisation until all cells were removed from the plastic. Then, trypsin was neutralised by the addition of a medium containing $10 \%$ FCS up to a final volume of $11 \mathrm{~mL}$. Cells were centrifuged at $130 \mathrm{~g}$ for $10 \mathrm{~min}$ and re-suspended in $5 \mathrm{~mL}$ PBS for counting.

\subsection{Parasite count}

Shape, density and intra or extracellular position of the tachyzoites were evaluated. Each series of 24 T25 flasks was incubated with $250000 \mathrm{NC}-1$ or $60000 \mathrm{RH}$ tachyzoites of $N$. caninum and T. gondii respectively. Parasite counts were performed on eight flasks for each parasite. Two flasks were used each day between day 3 and day 6 , post infection. Infected and non infected cells were collected with a cell scraper and then transferred into a 
$30 \mathrm{~mL}$ vessel. Cell suspensions were then passed through a 25 gauge needle in order to rupture remaining intact cells and to expel tachyzoites. The suspension was centrifuged for $20 \mathrm{~min}$ at $1350 \times \mathrm{g}$. The supernatant was discarded and the pellet was appropriately diluted in PBS depending on the concentration of the parasites. Counting was performed at $100 \times$ magnification using a Thoma haemocytometer.

\subsection{Statistical analysis}

Student t-test was performed to compare Vero cells or tachyzoite production on each day of the trial. Normality and equality of variance assumptions were evaluated by performing the Kolmogorov-Smirnov and Fischer exact tests respectively. Each time either normality or equality of variance were not carried out a Mann-Whitney test was used. In all other cases, p-level values were the result of the Student t-test.

\section{RESULTS}

\subsection{Cell evaluation}

\subsubsection{Qualitative evaluation}

Cell cultures consisted of Vero cells adapted to RPMI, supplemented either with $2 \%$ HS, $10 \%$ DefCell or $10 \%$ FCS. An average of 1500000 cells were put into culture in each T25 flask. Cells became confluent in all cases on day 3. A monolayer was observed when cells were maintained in the presence of HS or DefCell whereas cells cultured in the presence of FCS became hyper-confluent and contained some granules. Overgrowth was observed in all media on day 4. In media supplemented with HS and FCS, some cells were released from the plastic substrate. On day 5, overgrowth was very marked in a culture with an FCS supplemented medium and many round, granular cells were floating in the supernatant.
This was also observed to a lesser extent with Vero cells in the HS supplemented medium. In contrast, most cells maintained in the DefCell supplemented medium, were still alive and adherent, with the classical Vero elongated shape. At the end of the assay (day 7) HS and FCS supplemented media cells were almost all in suspension while DefCell cells were still adherent on the plastic substrate, without signs of lysis.

\subsubsection{Quantitative evaluation}

From a quantitative point of view, cell growth was better in the FCS supplemented medium (Fig. 1). Generally, numbers of cells doubled each day in FCS up to day 3, while they grew more slowly in the two other media. After day 3, FCS cell numbers reached a stationary phase and then declined between day 5 and 6 before increasing again on day 7 . This decrease was also observed in the HS medium between days 5 and 6. In contrast, DefCell cells grew regularly up to day 7 without showing any decline, except on day 7 , when cells became almost confluent. Significant differences between culture in FCS and the two others were observed throughout (with all $p<$ 0.00001 ) except on day six when no difference was found between FCS and the DefCell supplemented media. On day six, FCS cells were already in the final decline phase while in the other cases cells were still in their growth phase. When comparing cell production in DefCell and HS supplemented media, production in the former was significantly higher on days three and four $(p<0.00001$ and $p<0.003$ respectively) but lower on day $6(p<0.00001)$ whereas there was no statistical difference on day 5.

The DefCell medium seemed to promote a better cell survival than the two other media used. A decreased viability of $30 \%$ and $9 \%$ respectively on day 7 was observed with HS and DefCell media. 


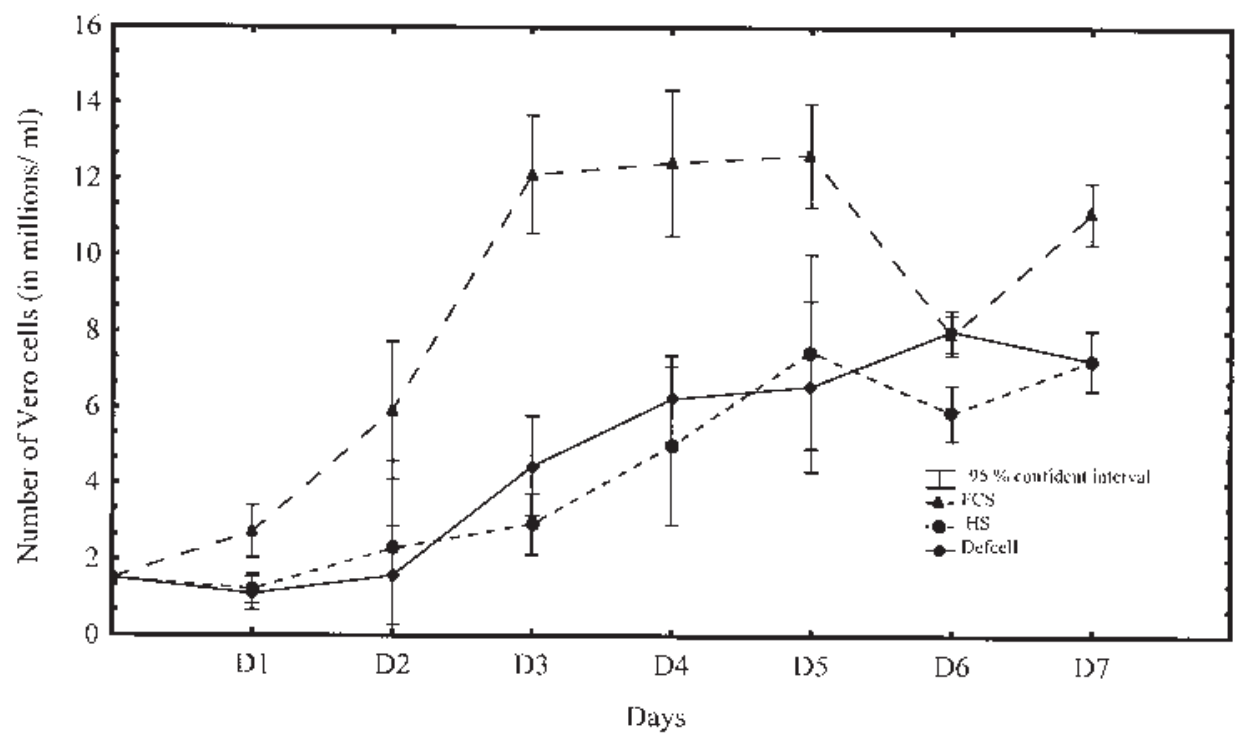

Figure 1. Vero cell production in three different supplemented media.

(FCS: media supplemented with 10\% foetal calf serum; HS: media supplemented with $2 \%$ horse serum; DefCell: media supplemented with 10\% additives from the Institut Pasteur of Paris.)

Kinetics in HS and DefCell show the same growth pattern while FCS cells rise rapidly up to day 5. FCS cells reach a plateau at day 3 while the other two still show growth at day 6 . On the contrary, cells growing in DefCell and HS supplements remained in a lag phase for two days before starting their exponential phase.

\subsection{Parasite growth}

\subsubsection{T. gondii tachyzoites}

One day after infection with $T$. gondii tachyzoites, cells showed an infection rate between 3 and $5 \%$ irrespective of the type of medium. On day 2, the infection rate increased very quickly in FCS cells reaching $50-70 \%$. The rate was around $30-40 \%$ in the HS medium while it remained between 5 and $10 \%$ in the DefCell medium. On day 3 , the rise was 60 to $80 \%$ in HS cells. On the contrary, lysis was now obvious in all cases, even in the DefCell cells, with the lowest infection rate. Surprisingly, FCS cells remained in good condition during the entire experimental period. No tachyzoites were observed in suspension and areas of lysis were rarely observed. In the other two media, lysis was around 30\% and many tachyzoites were observed in suspension. On days 6 and 7, no tachyzoites were observed in FCS cells. In contrast, they were commonly observed in lysis areas in both HS and DefCell media. From a quantitative point of view, HS and DefCell cells showed both an increase in the number of visible tachyzoites (Fig. 2). But in the former case, the number of tachyzoites seemed to reach a plateau on day 5 while those produced in the DefCell media increased up to day 6 to reach 9050000 parasites $/ \mathrm{mL}$. Tachyzoite production was significantly different between the two supplemented media from day 4 to 6 . Surprisingly, parasite production remained very low in cells grown in the FCS medium. 


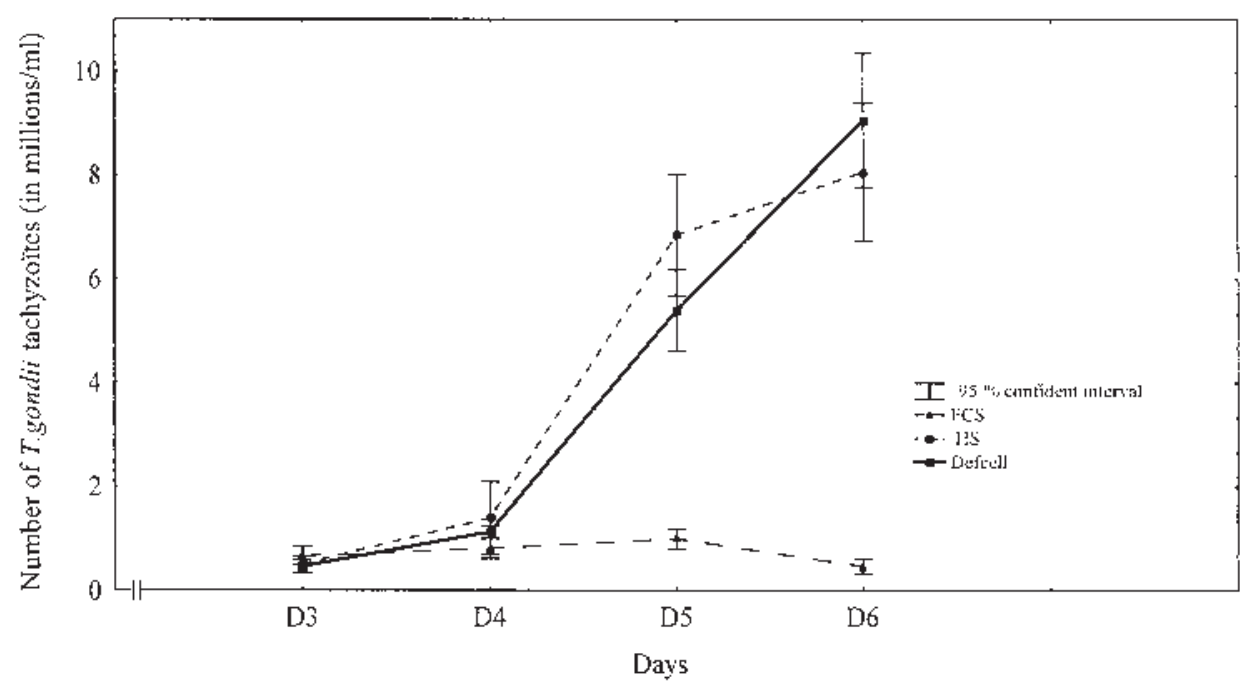

Figure 2. T. gondii tachyzoite production in three different supplemented media. Production starts after the "lag" phase in HS and DefCell, however it remains at a very low level for the entire experimental period in FCS. Both DefCell and HS are suitable for the production of T. gondii.

\subsubsection{N. caninum tachyzoites}

As in the case of $T$. gondii, 3 to $5 \%$ of the cells were infected with $N$. caninum tachyzoites on day 1 . On day $2,50-70$, $40-50$ and $30-40 \%$ of the cells were infected in FCS, HS and DefCell media respectively. In both FCS and DefCell conditions, few tachyzoites were present in suspension while $15-20 \%$ of the cells had ruptured. The HS medium showed 3 to $5 \%$ of lysis with no tachyzoites in suspension. On day 3, infection reached $90 \%$ in FCS with $50 \%$ of the cells being lysed. The results were similar in the HS medium, while the DefCell medium showed only 15-30\% lysis and $70 \%$ infected cells. Five days after the start of the experiment, almost all HS cells were destroyed while $70 \%$ of the DefCell cells were still intact. Nevertheless in this case, numerous tachyzoites were observed in suspension throughout the culture. Cell clusters containing tachyzoites in suspension were observed in both the FCS and HS media on days 5 and 6 while rounded tachyzoites were present in suspension in both HS and DefCell conditions. Tachyzoites were more evenly distributed in DefCell medium than in HS medium where they appeared in clusters.

Figure 3 indicates that $N$. caninum counts gave results which were very different from those obtained with $T$. gondii. Best production was achieved in FCS with a total count of $173 \times 10^{6}$ tachyzoites/mL on day 5 , with a decrease in parasite count observed by day 5 , probably related to the cell evolution observed during this period. Proliferation was very rapid, since $120 \times 10^{6}$ tachyzoites/mL were observed on day 4 while only $45 \times 10^{6}$ in HS and $37.5 \times 10^{6}$ organisms were observed in HS and DefCell media respectively. Significant differences were found between tachyzoite production on each day when all conditions were compared statistically. By comparing Figures 1 and 3, the maximum production of tachyzoites seemed to be related to the number of cells present in the flask. Indeed, 


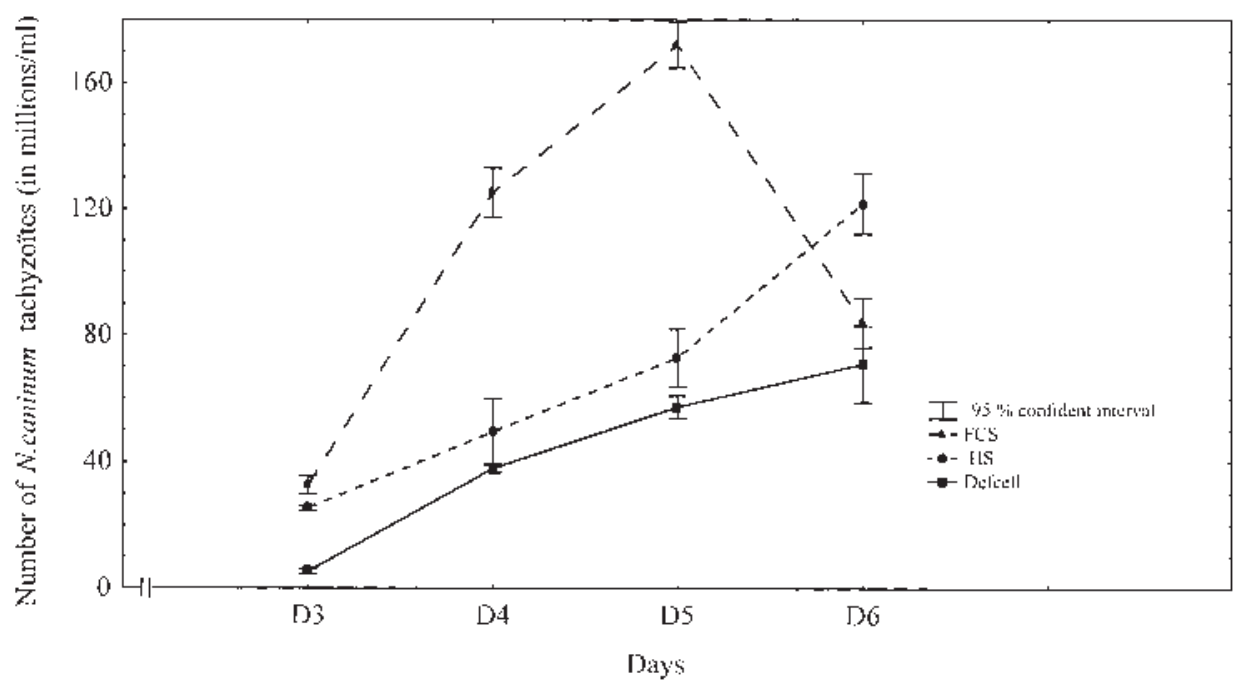

Figure 3. $N$. caninum tachyzoite production in the three different supplemented media. The production starts without any "lag" phase in the three different types of media. Both DefCell and HS are suitable for producing $N$. caninum, but FCS gives the best results in terms of the quantity of tachyzoites produced.

except on day 6 , maximum production was reached in the FCS medium on day 5 while in the other two supplemented media, production levels were $50-70 \times 10^{6}$ on the same day. Although the numbers observed within the DefCell condition were always lower than for HS, the increases followed the same trend.

\section{DISCUSSION}

In the present study, RPMI was used as the base medium supplemented with $10 \%$ FCS. Other supplements were added at concentrations of $2 \%$ for HS and $10 \%$ for DefCell. In the FCS medium, cell doubling time was $24 \mathrm{~h}$, during the exponential phase, while this period was expanded to $48 \mathrm{~h}$ and $56 \mathrm{~h}$ in HS, and DefCell media respectively. Clearly, FCS is more effective than the other supplements in promoting Vero cell proliferation. Cell kinetics in HS and DefCell show the same growth pattern with a lag phase of two days before entering an exponential phase while in the FCS, cell numbers rapidly reached a plateau on day 3 .

Currently, $T$. gondii tachyzoites are produced by serial passages in the peritoneal cavity of mice or cotton rats $[1,3,35,43]$. Although convenient and reliable, this technique is ethically undesirable. Alternative in vitro methods, using MRC5 fibro- blasts complemented with FCS, were used for short studies assessing the effect of antimicrobial agents on $T$. gondii $[3,10$, 21]. Additionally, continuous cell lines such as HeLa, LLC and Vero were also found to be suitable for the propagation of tachyzoites of $T$. gondii for the needs of a general hospital laboratory [19]. Recently, the good performances of the dye test [39] were reported with tachyzoites grown in cell cultures supplemented with FCS [1]. However, in the present study, FCS was 
unable to support adequate $T$. gondii parasite replication rates. The maximum number of tachyzoites produced was close to $10^{6}$ on day 5 while at the same time HS and DefCell yielded 7 and 5.5 times more parasites, respectively. The batch of FCS, used in this study, may have contained factors which adversely affected tachyzoite growth. HeLa cells were previously reported [19] as being more effective than Vero cells for the production of $T$. gondii tachyzoites in FCS supplemented medium. Since the primary goal of this study was the establishment of a serum free medium for the production of $N$. caninum tachyzoites, Vero cells were selected to support tachyzoite proliferation $[13,28,30]$. The use of HeLa cells adapted in the Defcell medium should give interesting results with $T$. gondii.

In the present work, $N$. caninum growth was better in FCS supplemented medium. However, the use of different batches of FCS could lead to irregular growth and various technical problems when performing serological tests such as IFAT (unpublished observation) and Defcell medium represents an interesting alternative.

In vitro cultures are also used to screen potential chemotherapeutic agents $[3,10$, $21,29,30]$ to study the process of cell invasion by the parasite [24] or perform genetic manipulation on the parasite $[25,38]$. The presence of serum proteins, or even specific antibodies, could hamper these experiments. The use of a chemically defined medium, such as the one used in the present work, could theoretically eliminate all these problems. In conclusion, for $T$. gondii culture, the Defcell medium should be regarded as a good alternative to the FCS supplemented medium due to the absence of animal protein and the satisfactory level of tachyzoite production whereas the Defcell medium is also able to provide regular supply or viable $N$. caninum tachyzoites more suitable for serological assays than the conventionally produced parasites. However Defcell medium is relatively expensive and it would be useful to compare it under the same conditions with IgG free horse serum which could be a cheaper alternative.

\section{AKNOWLEDGEMENTS}

The authors especially thank Dr D. Buxton (Moredun Research Institute, Edinburgh, UK) and the Janssen Reseach Foundation (Beerse, Belgium) for providing us with the $N$. caninum isolate and the $\mathrm{RH}$ strain of $T$. gondii respectively. We thank also Dr O'Brien (Veterinary Research Laboratory, Dublin, Ireland) for useful comments on the manuscript. This work was supported by grant No $5774 \mathrm{~A}$ from the Federal Ministry of Agriculture Section Research Development, Belgium.

\section{REFERENCES}

[1] Ashburn D., Evans R., Chatterton J.M., Joss A.W., Ho-Yen D.O., Toxoplasma dye test using cell culture derived tachyzoites, J. Clin. Pathol. 53 (2000) 630-633.

[2] Barr B.C., Anderson M.L., Sverlow K.W., Conrad P.A., Diagnosis of bovine fetal Neospora infection with an indirect fluorescent antibody test, Vet. Rec. 137 (1995) 611-613.

[3] Benoit-Vical F., Santillana-Hayat M., KoneBamba D., Mallie M., Derouin F., AntiToxoplasma activity of vegetal extracts used in West African traditional medicine, Parasite 7 (2000) 3-7.

[4] Bjorkman C., Lunden A., Application of iscom antigen preparations in ELISAs for diagnosis of Neospora and Toxoplasma infections, Int. J. Parasitol. 28 (1998) 187-193.

[5] Bjorkman C., Uggla A., Serological diagnosis of Neospora caninum infection, Int. J. Parasitol. 29 (1999) 1497-1507.

[6] Bjorkman C., Lunden A., Holmdahl J., Barber J., Trees A.J., Uggla A., Neospora caninum in dogs: detection of antibodies by ELISA using an iscom antigen, Parasite Immunol. 16 (1994) 643-648.

[7] Buxton D., Protozoan infections (Toxoplama gondii, Neospora caninum and Sarcocystis spp.) in sheep and goats: recent advances, Vet. Res. 29 (1998) 289-310.

[8] Cheadle M.A., Lindsay D.S., Rowe S., Dykstra C.C., Williams M.A., Spencer J.A., ToivioKinnucan M.A., Lenz S.D., Newton J.C., 
Rolsma M.D., Blagburn B.L., Prevalence of antibodies to Neospora sp. in horses from Alabama and characterisation of an isolate recovered from a naturally infected horse, Int. J. Parasitol. 29 (1999) 1537-1543.

[9] Conrad P.A., Sverlow K., Anderson M., Rowe J., BonDurant R., Tuter G., Breitmeyer R., Palmer C., Thurmond M., Ardans A., Detection of serum antibody responses in cattle with natural or experimental Neospora infections, J. Vet. Diagn. Invest 5 (1993) 572-578

[10] Derouin F., Chastang C., Enzyme immunoassay to assess effect of antimicrobial agents on Toxoplasma gondii in tissue culture, Antimicrob. Agents Chemother. 32 (1988) 303-307.

[11] De Meerschman F., Czaplicki G., Focant C., Boreux R., Leclipteux T., Losson B., Cattle neosporosis in Belgium: a case-control study in dairy and beef cattle, in: Hemphill A., Gottstein B. (Eds)., A European perspective on Neospora caninum, Int. J. Parasitol. 30 (2000) 877-924.

[12] Dubey J.P., Lindsay D.S., A review of Neospora caninum and neosporosis, Vet. Parasitol. 67 (1996) 1-59.

[13] Dubey J.P., Hattel A.L., Lindsay D.S., Topper M.J., Neonatal Neospora caninum infection in dogs: isolation of the causative agent and experimental transmission, J. Am. Vet. Med. Assoc. 193 (1988) 1259-1263.

[14] Dubey J.P., Carpenter J.L., Speer C.A., Topper M.J., Uggla A., Newly recognized fatal protozoan disease of dogs, J. Am. Vet. Med. Assoc. 192 (1988) 1269-1285.

[15] Dubey J.P., Lindsay D.S., Adams D.S., Gay J.M., Baszler T.V., Blagburn B.L., Thulliez P., Serologic responses of cattle and other animals infected with Neospora caninum, Am. J. Vet. Res. 57 (1996) 329-336.

[16] Dubey J.P., Dorough K.R., Jenkins M.C., Liddell S., Speer C.A., Kwok O.C., Shen S.K., Canine neosporosis: clinical signs, diagnosis, treatment and isolation of Neospora caninum in mice and cell culture, Int. J. Parasitol. 28 (1998) 1293-1304.

[17] Dubey J.P., Romand S., Thulliez P., Kwok O.C., Shen S.K., Gamble H.R., Prevalence of antibodies to Neospora caninum in horses in North America, J. Parasitol. 85 (1999) 968-969.

[18] Ellis J.T., Polymerase chain reaction approaches for the detection of Neospora caninum and Toxoplasma gondii, Int. J. Parasitol. 28 (1998) 1053-1060.

[19] Evans R., Chatterton J.M., Ashburn D., Joss A.W., Ho-Yen D.O., Cell-culture system for continuous production of Toxoplasma gondii tachyzoites, Eur. J. Clin. Microbiol. Infect. Dis. 18 (1999) 879-884.

[20] Gottstein B., Hentrich B., Wyss R., Thur B., Busato A., Stark K.D., Muller N., Molecular and immunodiagnostic investigations on bovine neosporosis in Switzerland, Int. J. Parasitol. 28 (1998) 679-691.

[21] Gozalbes R., Brun-Pascaud M., GarciaDomenech R., Galvez J., Girard P.M., Doucet J.P., Derouin F., Anti-toxoplasma activities of 24 quinolones and fluoroquinolones in vitro: prediction of activity by molecular topology and virtual computational techniques, Antimicrob. Agents Chemother. 44 (2000) 2771-2776.

[22] Hemphill A., The host-parasite relationship in neosporosis, Adv. Parasitol. 43 (1999) 47-104.

[23] Hemphill A., Gottstein B., A European perspective on Neospora caninum, Int. J. Parasitol. 30 (2000) 877-924.

[24] Hemphill A., Gottstein B., Kaufmann H., Adhesion and invasion of bovine endothelial cells by Neosporacaninum, Parasitol. 112(1996) 183-197.

[25] Howe D.K., Mercier C., Messina M., Sibley L.D., Expression of Toxoplasma gondii genes in the closely-related apicomplexan parasite Neospora caninum, Mol. Biochem. Parasitol. 86 (1997) 29-36.

[26] Lally N.C., Jenkins M.C., Dubey J.P., Evaluation of two Neospora caninum recombinant antigens for use in an enzyme-linked immunosorbent assay for the diagnosis of bovine neosporosis, Clin. Diagn. Lab. Immunol. 3 (1996) 275-279.

[27] Lindsay D.S., Dubey J.P., Immunohistochemical diagnosis of Neospora caninum in tissue sections, Am. J. Vet. Res. 50 (1989) 1981-1983.

[28] Lindsay D.S., Speer C.A., Toivio-Kinnucan M.A., Dubey J.P., Blagburn B.L., Use of infected cultured cells to compare ultrastructural features of Neospora caninum from dogs and Toxoplasma gondii, Am. J. Vet. Res. 54 (1993) 103-106.

[29] Lindsay D.S., Butler J.M., Rippey N.S., Blagburn B.L., Demonstration of synergistic effects of sulfonamides and dihydrofolate reductase/thymidylate synthase inhibitors against Neospora caninum tachyzoites in cultured cells, and characterization of mutants resistant to pyrimethamine, Am. J. Vet. Res. 57(1996)68-72.

[30] Lindsay D.S., Butler J.M., Blagburn B.L., Efficacy of decoquinate against Neospora caninum tachyzoites in cell cultures, Vet. Parasitol. 68 (1997) 35-40.

[31] Marsh A.E., Barr B.C., Packham A.E., Conrad P.A., Description of a new Neospora species (Protozoa: Apicomplexa: Sarcocystidae), J. Parasitol. 84 (1998) 983-991.

[32] Obwaller A., Hassl A., Picher O., Aspock H., An enzyme-linked immunosorbent assay with whole trophozoites of Toxoplasma gondii from serum-free tissue culture for detection of specific antibodies, Parasitol. Res. 81 (1995) 361-364.

[33] Pare J., Hietala S.K., Thurmond M.C., Interpretation of an indirect fluorescent antibody test for diagnosis of Neospora sp. infection in cattle, J. Vet. Diagn. Invest. 7 (1995) 273-275.

[34] Pare J., Hietala S.K., Thurmond M.C., An enzyme-linked immunosorbent assay (ELISA) for 
serological diagnosis of Neospora sp. infection in cattle, J. Vet. Diagn. Invest. 7 (1995) 352-359.

[35] Petersen E., Pollak A., Reiter-Owona I., Recent trends in research on congenital toxoplasmosis, Int. J. Parasitol. 31 (2001) 115-144.

[36] Perl S., Harrus S., Satuchne C., Yakobson B., Haines D., Cutaneous neosporosis in a dog in Israel, Vet. Parasitol. 79 (1998) 257-261.

[37] Poli A., Mancianti F., Carli M.A., Stroscio M.C., Kramer L., Neospora caninum infection in a Bernese cattle dog from Italy, Vet. Parasitol. 78 (1998) 79-85.

[38] Radke J.R., Guerini M.N., White M.W., Toxoplasma gondii: characterization of temperature-sensitive tachyzoite cell cycle mutants, Exp. Parasitol. 96 (2000) 168-177.

[39] Sabin A.B., Feldman H.A., Dyes as microchemical indicators of a new immunity phenom enon affecting a protozoon parasite (Toxoplasma), Science 108 (1948) 660-663.

[40] Soulsby E.J.L., Helminths, arthropods and protozoa of domesticated animals, Baillière Tindall, London, 1982.

[41] Tranas J., Heinzen R.A., Weiss L.M., McAllister M.M., Serological evidence of human infection with the protozoan Neospora caninum, Clin. Diagn. Lab. Immunol. 6 (1999) 765-767.

[42] Uggla A., Stenlund S., Holmdahl O.J., Jakubek E.B., Thebo P., Kindahl H., Bjorkman C., Oral Neospora caninum inoculation of neonatal calves, Int. J. Parasitol. 28 (1998) 1467-1472.

[43] Villavedra M., Rampoldi C., Carol H., Baz A., Battistoni J.J., Nieto A., Identification of circulating antigens, including an immunoglobulin binding protein, from Toxoplasma gondii tissue cyst and tachyzoites in murine toxoplasmosis, Int. J. Parasitol. 31 (2001) 21-28.

[44] Williams D.J., McGarry J., Guy F., Barber J., Trees A.J., Novel ELISA for detection of Neospora-specific antibodies in cattle, Vet. Rec. 140 (1997) 328-331.

[45] Wouda W., Diagnosis and epidemiology of bovine neosporosis: a review, Vet. Q. 22 (2000) 71-74.

[46] Wouda W., Moen A.R., Visser I.J., van Knapen F., Bovine fetal neosporosis: a comparison of epizootic and sporadic abortion cases and different age classes with regard to lesion severity and immunohistochemical identification of organisms in brain, heart, and liver, J. Vet. Diagn. Invest. 9 (1997) 180-185.

To access this journal online:

www.edpsciences.org 